\title{
Intraspecific variation of a dominant Caribbean reef building coral, Montastrea annularis: genetic, behavioral and morphometric aspects
}

\author{
Manfred L. J. Van Veghel ${ }^{1,2}$, Rolf P. M. Bak $^{2,3}$ \\ ${ }^{1}$ CARMABI Institute, PO Box 2090, Curaçao, Netherlands Antilles \\ ${ }^{2}$ University of Amsterdam, Institute of Taxonomic Zoology, PO Box 4766, 1009 AT Amsterdam, The Netherlands \\ ${ }^{3}$ Netherlands Institute for Sea Research (NIOZ), PO Box 59, 1790 AB Den Burg, Texel, The Netherlands
}

\begin{abstract}
We investigated intraspecific variation of the dominant Caribbean reef building coral Montastrea annularis (Ellis \& Solander) in terms of genetic variation (protein electrophoresis), intraspecific interaction and micro/macro morphometry. Our study included 3 sympatric morphotypes, 'Bumpy', 'Massive' and 'Columnar', distinguishable within $M$. annularis populations on the leeward coasts of Curaçao and Bonaire (Netherlands Antilles). The genetic study demonstrated 8 polymorphic and 1 monomorphic loci. The mean number of alleles over all loci was 4.7 , and the average heterozygosity $(H)$ over all loci examined was high $(0.36)$. One out of 9 taxonomic units showed a significant heterozygote deficiency; the others matched expectation. The $M$. annularis morphotypes showed a significant variation in allele frequencies but no fixed differences were found. The 'Columnar' and 'Bumpy' morphotypes were more similar with a genetic distance of 0.07 . The 'Massive' morphotype demonstrated larger genetic distances: 0.13 with 'Columnar' and 0.16 with 'Bumpy' The 'Bumpy' morphotype was dominant over the other 2 morphotypes in the intraspecific interaction experiments, and 'Massive' was dominant over 'Columnar' The percentage of interactions was lower in intra-morphic experiments. Of the 22 micro-morphometric parameters examined, 14 showed significant differences between the 3 morphs. In addition the mean number of polyps per $\mathrm{cm}^{2}$ was very different: values ranged from 28.55 for 'Bumpy' to 40.97 for 'Columnar'
\end{abstract}

\section{INTRODUCTION}

That corals display a high morphological plasticity is well known (Wood-Jones 1907, Stephenson \& Stephenson 1933, Barnes 1973, Foster 1979). However importance of this variation in relation to evolutionary and life history tactics is not well understood. More understanding is required on relations between genotypic and phenotypic variation as well as phenotypic variation and fitness in different environments.

The factors reported to cause intraspecific variation are abiotic factors (Roos 1967, 1971, Barnes 1973, Dustan 1975, Foster 1977, 1979, Graus \& Macintyre 1982) and genetic variation (Ohlhorst 1979, Stoddart 1984a, b. Willis \& Ayre 1985, Ayre et al. 1991). Understanding colony morphology in relation to environmental parameters is very difficult because of lack. of understanding of ecological strategies of the taxa, for example feeding and sediment removal mechanisms (Wijsman-Best 1974, Foster 1977, 1979).

As a taxonomic tool at interspecific and intraspecific levels, enzyme electrophoresis is well known (Thorpe 1983). This technique has been used in coral research (Ohlhorst 1979, Stoddart 1984a, b, Ayre et al. 1991), sometimes combined with histocompatibility experiments (Willis \& Ayre 1985). The shortage of data sets combining genetic variation with morphological and environmental data, however, makes comparisons between morphologically variable taxa difficult. More genetic analyses are required to achieve a better understanding of breeding systems and population biology of corals (Stoddart 1983), e.g. heterozygosity values, Hardy-Weinberg equilibria and genetic distances.

Montastrea annularis (Ellis \& Solander) and Acropora palmata (Lamarck) are recognized as major reef framework builders of Atlantic reefs (Van Duyl 1985). 
Since the recent decline of $A$. palmata throughout much of its range due to disease and effects of pollution (Gladfelter 1982, Van Duyl 1985), M. annularis may be the most important species in terms of reef structure and reef habitat building. It is probably the most frequently investigated Atlantic coral species. Aspects investigated include growth and form (Dustan 1975, Hudson 1981a, b, Graus \& MacIntyre 1982, Goenaga 1988), carbon budgets (Porter 1985), eutrophication (Tomascik \& Sander 1987), regeneration (Bak et al. 1977, Lester \& Bak 1985), survival and mortality (Bak \& Engel 1979, Bak \& Luckhurst 1980, Hughes \& Jackson 1980), morphometrics (Foster 1977, 1979), genetics (Ohlhorst 1979, Knowlton et al. 1992), interspecific interactions (Lang 1973, Bak et al. 1982), reproduction (Szmant-Froelich 1985, Szmant 1986), sediment rejection (Szmant-Froelich et al. 1981, Dodge 1982, Parker et al. 1984), black band disease (RamosFlores 1983), and bleaching (Hayes \& Bush 1990 , Szmant \& Gassman 1990, Meesters \& Bak 1993). Barnes (1973) previously reported several growth forms of $M$. annularis, but until recently (Tomascik 1990, Knowlton et al. 1992) most studies neglected to describe the morphotype studied. If $M$. annularis is to be used as a biological monitor in Atlantic reefs, as suggested (Ogden \& Gladfelter 1986, Tomascik 1990), a proper description of differences in life history aspects in relation to growth form variability is required. This is because repudiating the variability of growth form may lead to higher variability in research outcome and misinterpretation of the data when data sets of different places and researchers are compared.

This study presents our first results on intraspecific variation in the Montastrea annularis communities at Curaçao. We distinguished 3 different sympatric morphotypes: 'Bumpy', 'Massive' and 'Columnar', and will treat differences in (1) genetic variation (protein electrophoretic), (2) intraspecific interactions, and (3) micro/macro morphometry.

\section{MATERIAL AND METHODS}

Morphotypes. The 3 morphotypes of Montastrea annularis are illustrated in Fig. 1. These sympatric growth forms are strikingly different and easily distinguishable underwater:

(1) 'Bumpy' (B): Colonies are massive. Polyps are irregularly oriented and usually larger than those in other morphotypes. The tissue is usually brown, though white or discolored spots are often present. This morphotype is found from intermediate to deep water $(10$ to $45 \mathrm{~m})$. Collections were made between 11.5 and $27 \mathrm{~m}$. Equivalent names are 'Irregularmassive' (Barnes 1973), 'Lumpy-massive' or 'Flat plates with lumpy surfaces' (Dustan 1975), or 'Morphotype 3' (Knowlton et al. 1992).

(2) 'Massive' (M): Massive colony whose surface can be smooth, raised with knobs, or extended in ridges. The tissue is green or brown. Often, the oral disk is colored lighter. The polyps are uniformly arranged. This morphotype is abundant between 1 and $30 \mathrm{~m}$. In deeper water $(10$ to $30 \mathrm{~m})$ colonies usually form rosettes of separate plates on the lower sides of the colony. Collections were made between 3.5 and $20.5 \mathrm{~m}$. In earlier studies this morphotype is reported as 'Platelike' or 'Rounded colonies' (Barnes 1973), 'Roundbulbous', 'Skirted massive hemispherical' or 'Flat-plate colonies' (Dustan 1975), 'Lobate' (Tomascik 1990), or 'Morphotype 2' (Knowlton et al. 1992).

(3) 'Columnar' (C): Colonies consist of pillar-like columns with a smooth surface. Tissue is only found over the apex of columns. Polyps are usually brown, including the oral disk, and uniformly arranged. This morphotype occurs between 1 and $30 \mathrm{~m}$ deep but is more abundant in shallow waters. For our study, it was collected between 3.5 and $20 \mathrm{~m}$. 'Columnar-lobate' (Barnes 1973), 'Knobby-massive', 'Columnar-lobate' (Dustan 1975), 'Columnar' (Tomascik 1990), or 'Merphotype 1' (Knowlton at al. 1992) may be considered as equivalent.

Material. Specimens of the Montastrea annulans morphotypes were collected at 3 localities on the leeward coast of Curaçao (Fig. 2): Awa Blancu (AB), CARMABI buoy 1 (B1) and Slangenbaai (SB). The distances between the sites are 20 and $4 \mathrm{~km}$, respectively. At each locality corals were collected within an area of $400 \mathrm{~m}$. For description of the sites, see Van Duyl (1985). Parts of colonies were collected haphazardly, avoiding intermediate forms, using hammer and chisel. All collections and field observations were made using SCUBA.

Electrophoretic analyses. Sample collection and preparation: For each of the 3 study sites, 25 individuals per morphotype were sampled. After removing epiphytic organisms, corals were transported in seawater to a laboratory running seawater system. In the laboratory the living coral tissue and underlying skeleton were scraped off with a chisel, placed in a cryovial containing a few drops of grinding buffer (Stoddart 1983), frozen, and immediately stored in liquid nitrogen.

Electrophoresis: Electrophoretic procedures were performed upon 15 individuals of each population following the methods and terminology of the Montastrea annularis data by Knowlton et al. (1992). Our investigation was performed at the same laboratory (STRI, Panama).

Samples were ground by hand on cold plates with several drops of grinding buffer (Stoddart 1983). Before soaking filter paper in the protein solution, a 

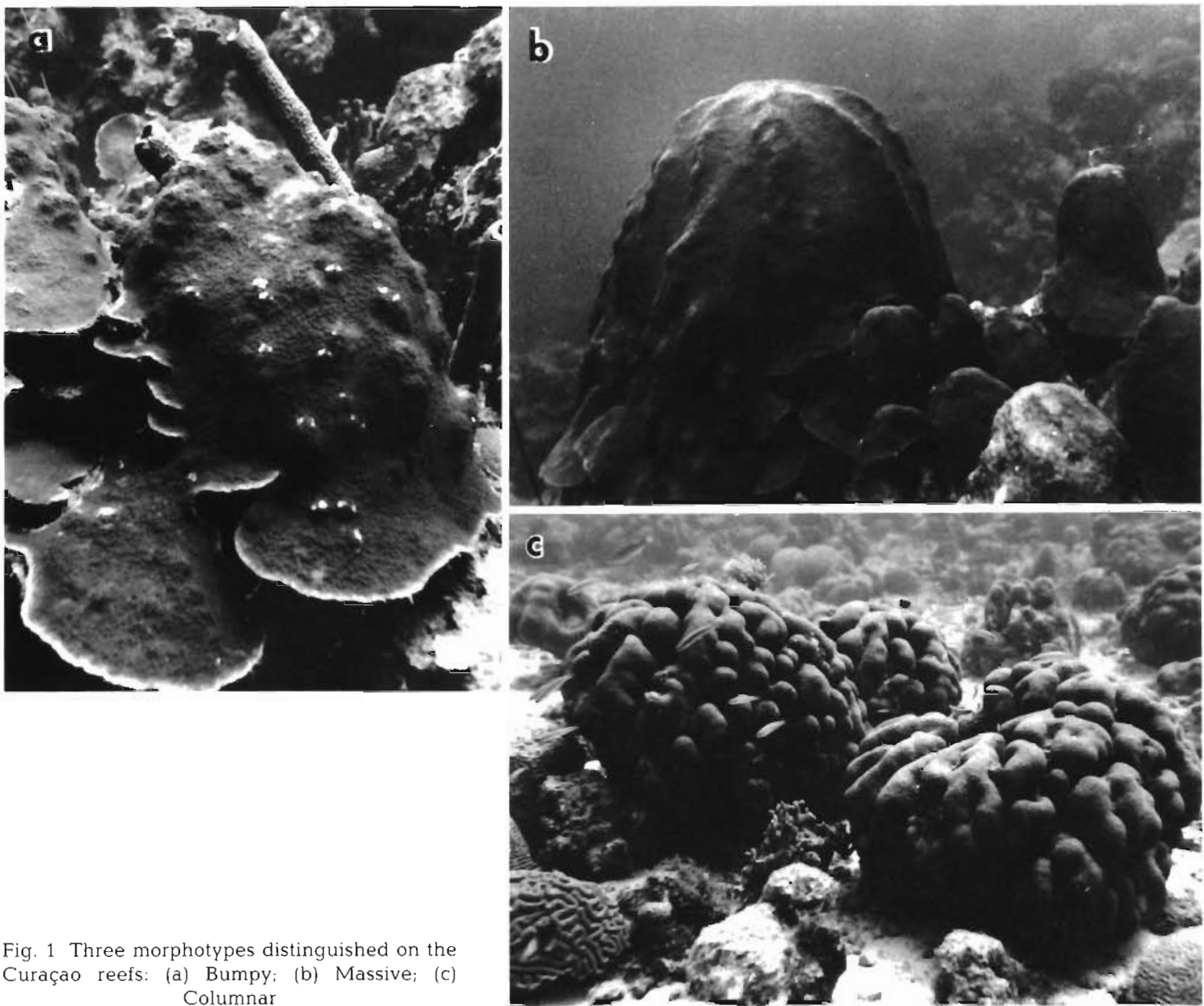

Fur 1 Three morphotypes distinguished on the Curaçao reefs: (a) Bumpy; (b) Massive; (c) Columnar

Leucyl-Tyrosine Peptidase (LTP), Leucyl-Proline Peptidase (LPP). The products of the last 7 stainings showed a consistent and usable pattern. In the final screening process 2 different buffer systems and 7 stainings were used: the TC 8.0 buffer for GPI, ME, GDH and PGM and the LiOH buffer for TPI, LTP and LPP. As a control we used one colony of Tubastrea coc cinea (Lesson), which showed a consistent and clear pattern in all of the stainings; $T$. coccinea was chosen because it is easy to collect and to grind.

Allele frequencies, heterozygosity $(H)$, Nei's unbiased genetic distance (D) and identity $(I)$ indices (Nei 1978) were computed. The hypotheses that each population is in Hardy-Weinberg equilibrium was tested with Chi-square tests. Analyses were performed using the BIOSYS-1 (release 1.7) computer program of Swofford \& Selander (1981).

Intra-colony variance: In order to insure that isolated parts of the same colony are ramets, 2 isolated drogenase (GDH), Triosephosphate Isomerase (TPI), 


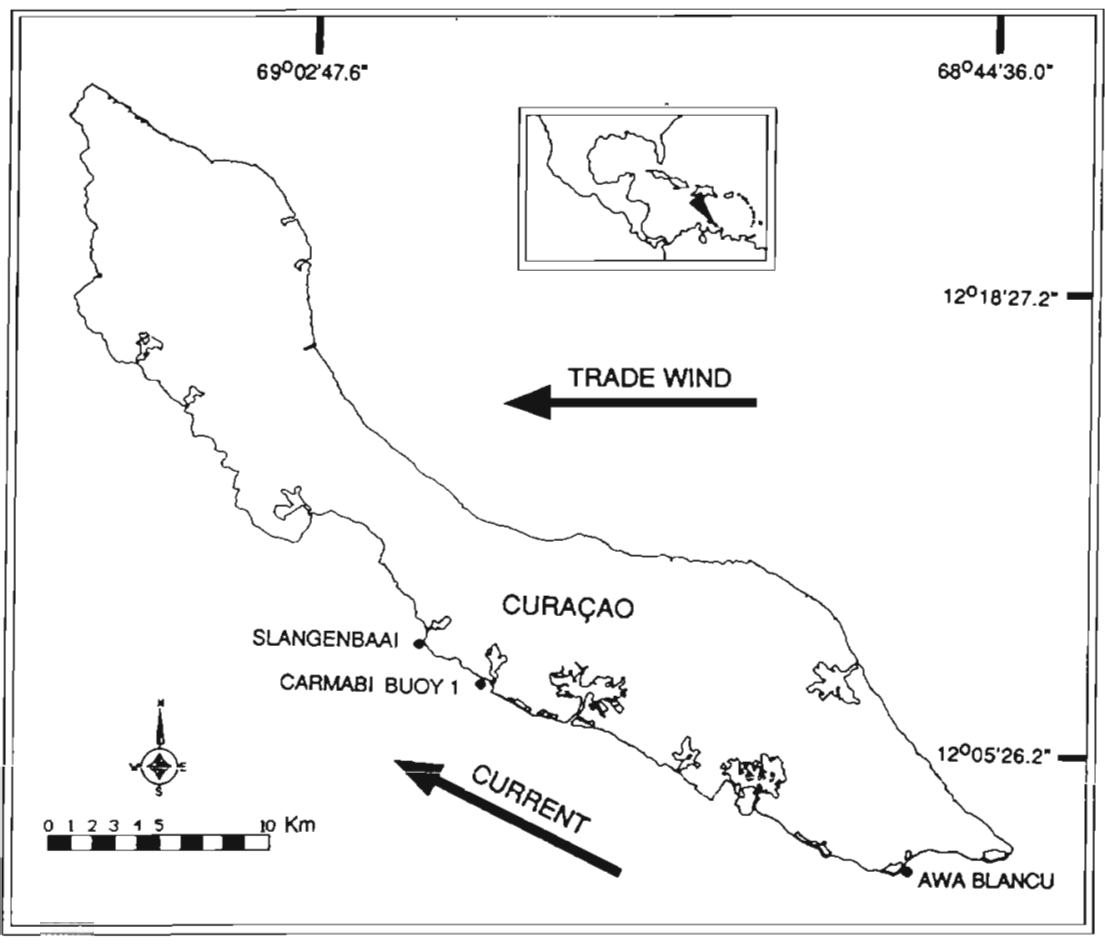

Fig. 2. Location of sampling stations on Curaçao, Netherlands Antilles

contact area were measured with calipers to the nearest $0.1 \mathrm{~mm}$. Categories were: (1) no interaction: coral tissue undamaged; (2) equally aggressive: coral tissue of both interacting colonies damaged, the ratio between the damaged areas being less than 2 ; (3) dominant: one colony not damaged or slightly damaged (ratio between damaged areas greater than 2). When a pair of experimental colonies was disturbed, i.e. not in contact, it was not included in the analysis. Chi-square tests for 2 independent samples (Siegel 1956) were performed to compare experiments.

Comparisons of electrophoretic and interaction experiments. Altogether 47 non-isogenic interaction pairs were included in the electrophoretic analyses. The percentage of alleles shared by each pair was correlated with the results of interactions. Correlations were tested using a single classification

parts from one colony were collected and electrophoretically screened running next to each other (total: 5 Massive and 3 Columnar).

Interaction experiments. Sample collection and setup: To study aggressive interaction corals were collected and placed in contact at a depth of 4 to $6 \mathrm{~m}$ (Location B1), Interaction pairs were examined at intervals over a period of up to $30 \mathrm{~d}$. We carried out 3 different interaction experiments:

(1) Isogenic contacts: 2 parts of the same colony were placed in contact $(\mathrm{n}=$ 240)

(2) Intra-morphic contacts: 2 parts of the same morphotype, but from different colonies, were placed in contact $(n=176)$.

(3) Inter-morphic contacts: coral parts of different morphotypes were placed in contact ( $n=179$ ).

To avoid possible complications due to the 1990 coral bleaching event (Meesters \& Bak 1993), we performed our experiments between July and September 1990 and January and February 1991.

Interpretation of results: At each survey of the interaction series all interactions for each coral were scored and used as data points in the analysis. The maximal length of damage and length of the

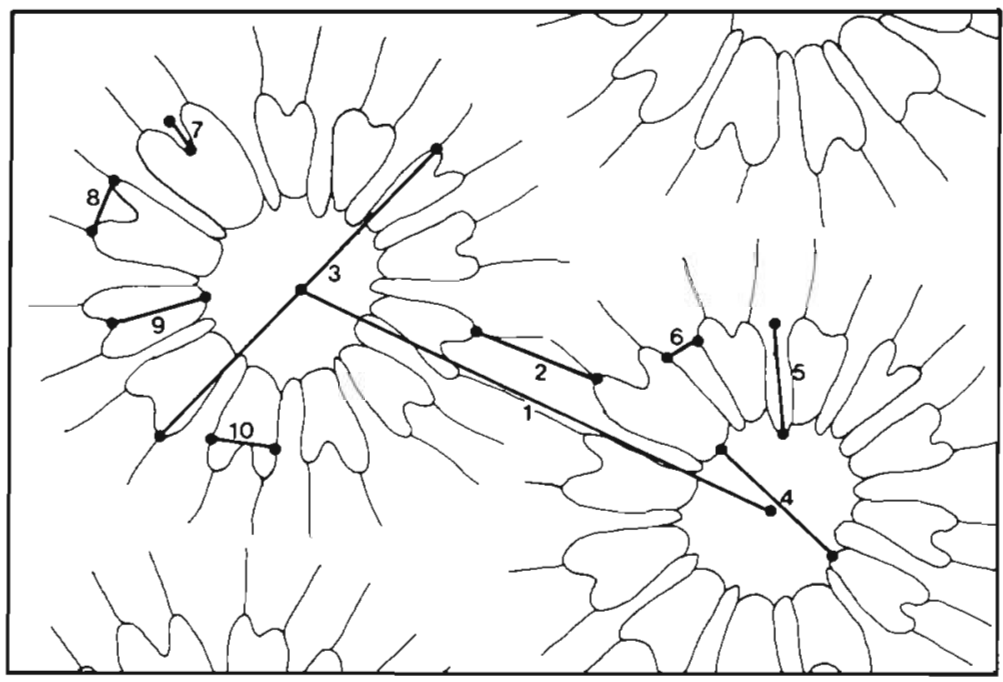

Fig. 3. Corallite showing 10 of the 12 micro-morphometric measurements 
Table 1. List of morphometric measurements of Montastrea annularis as illustrated in Fig. 3

\begin{tabular}{|c|c|c|c|}
\hline No. & Character & Abbr. & Description \\
\hline 1 & Columella distance & CuD & $\begin{array}{l}\text { Linear measure from columella centre to neighboring col- } \\
\text { umella centre }\end{array}$ \\
\hline 2. & Corallite spacing & Cas & $\begin{array}{l}\text { Linear measure between theca/coenosteum margins of neigh- } \\
\text { boring corallites }\end{array}$ \\
\hline 3. & Corallite diameter & $\mathrm{CaD}$ & $\begin{array}{l}\text { Linear measure between theca/corallite cavity margins across } \\
\text { the columella }\end{array}$ \\
\hline 4. & Columella width & CuW & $\begin{array}{l}\text { Linear measure between outer columella/corallite cavity } \\
\text { margins }\end{array}$ \\
\hline 5. & Primary septa length & PsL & $\begin{array}{l}\text { Linear measure between theca/corallite cavity margin and } \\
\text { outer columella/corallite cavity margin }\end{array}$ \\
\hline 6. & Primary septa thickness & PsT & $\begin{array}{l}\text { Linear measure of exoseptum thickness; measured at the } \\
\text { outer theca/corallite cavity }\end{array}$ \\
\hline 7. & Secondary septa length & SsL & $\begin{array}{l}\text { Linear measure between entoseptum tip and theca/columella } \\
\text { margins }\end{array}$ \\
\hline 8. & Secondary septa thickness & SsT & $\begin{array}{l}\text { Linear measure of exoseptum thickness; measured at the } \\
\text { outer theca corallite cavity }\end{array}$ \\
\hline 9. & Theca length & ThL & $\begin{array}{l}\text { Linear measure from entoseptum tip to outer columella/coral- } \\
\text { lite margins }\end{array}$ \\
\hline 10. & Theca width & ThW & $\begin{array}{l}\text { Linear measure of theca thickness, measured just above the } \\
\text { entoseptum tip }\end{array}$ \\
\hline 11. & Primáry septa count & PsC & Number of 1 st and 2 nd cycle septa \\
\hline 12. & Secondary septa count & $\mathrm{SsC}$ & Number of highest cycle septa \\
\hline
\end{tabular}

corallites, located at least $2 \mathrm{~cm}$ from the colony edge, were examined using the JAVA V1.20 program (Jandel Scientific, Corte Madera, CA). In Columnar morphotypes, 5 corallites at the apex and on the side were examined. Mean and standard deviation of all corallite characters were computed for each colony and each morphotype. Single classification ANOVA's with 2 and 3 groups were used to test significant differences between the measurements (Sokal \& Rohlf 1981).

Macro-morphometrics: In 268 coral fragments, the number of calices in a standard circle of $7.6 \mathrm{~cm}^{2}, 10-$ cated at least $1 \mathrm{~cm}$ off the colony edge, were counted. Columnar colonies were surveyed at the apex as well as on the side. A 2-way ANOVA (Sokal \& Rohlf 1981) was used to test if there was a significant difference between localities and morphotypes.

\section{RESULTS}

\section{Electrophoresis}

The electrophoretic analyses were encoded by 8 polymorphic and one monomorphic loci for 3 Montastrea annularis morphotypes (total $n=135$ ) at the 3 localities. Isozymes were identified by their anodal mobility, where A migrated further than B. An exception was made with the Tpi-2 locus allele $J$ which migrates further than the A allele on this locus. After screening the allelic composition of all samples, we can conclude that all individuals showed a unique genotypic pattern. The 8 colonies tested for intra-colony variation showed the same allele pattern.

Allelic frequencies. Table 2 shows the allele frequencies for the 9 examined loci. Although the frequency distributions of the morphotypes were significantly different ( $G$-test, $\mathrm{p}<0.001$ ), none of the loci was found to be diagnostic. The Me-1 locus, with 6 alleles, was found to be most variable; the $C(0.35,0.06$ and $0.25), D(0.55,0.11$ and 0.51$)$, and $E(0.06,0.71$ and 0.08 ) alleles showed the highest variation for Bumpy, Massive and Columnar respectively. The mean number of alleles per locus was calculated at 4.7 .

Heterozygosity. The mean observed heterozygosity $(H)$ values per locus ranged from 0.290 for Columnar (Location SB) to 0.44 for Massive (Location AB). The mean observed heterozygosity, $H$, (standard error) values per morphotype were: Bumpy $=0.34$ (0.08); Massive $=0.38(0.09)$; and Columnar $0.37(0.07)$.

Hardy-Weinberg equilibrium. Chi-square tests demonstrated that $25 \%$ of the polymorphic loci tested departed highly $(p<0.06)$; and $17 \%$ significantly 
Table 2. Montastrea annularis. Allele frequencies at 9 loci in 3 morphotypes of coral from sampling sites in Curaçao

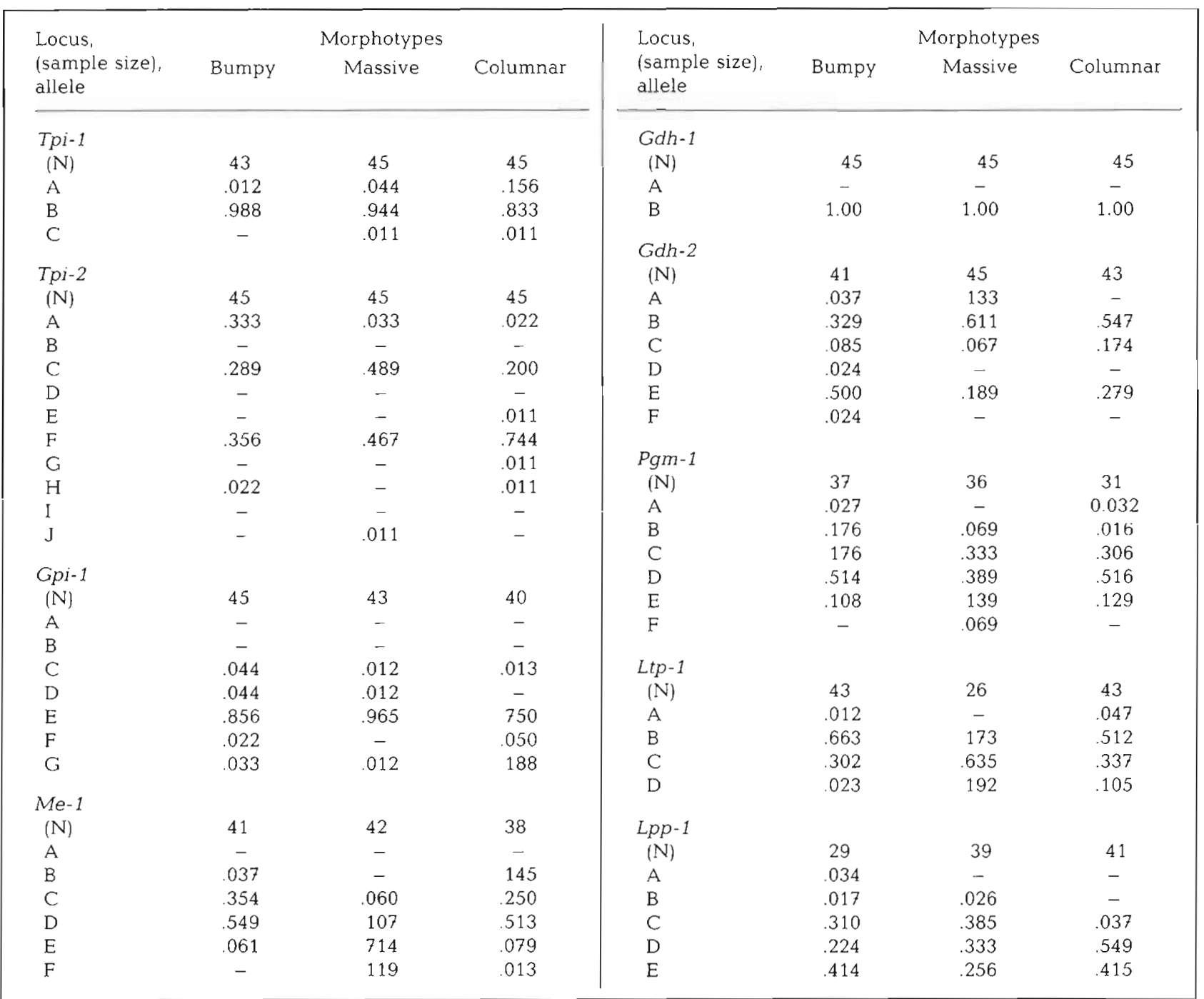

$(\mathrm{p}<0.05)$; from the Hardy-Weinberg equilibrium (Table 3). For the loci Pgm-1 and Lpp-1, this was $56 \%$. Although there was a general deficiency in the observed number of heterozygotes, only one taxonomic unit, B/SB (G-test, $p<0.005$ ), was significantly different from the expected value. Only the taxonomic unit $\mathrm{M} / \mathrm{AB}$ showed a heterozygote excess.

Genetic distance and similarity. Coefficients of unbiased genetic distance and similarity were calculated and clustered comparing the 3 morphotypes at 3 locations: a total of 9 operational taxonomic units. The dendogram (Fig. 4) shows the genetic differentiation between these taxonomic units. These results demonstrate that the morphotypes Columnar and Bumpy are more similar, with values of 0.07 (0.93), compared to the Massive morphotype, with values of $0.13(0.88)$ and $0.16(0.86)$ average genetic distance and similarity, respectively. Samples from the same morphotype clearly cluster together. Clustering is not consistent in terms of the geographic position of the different locations.

\section{Interaction experiments}

Tissue lesions, formed as a result of digestive mesenterial filaments, were observed the day after the beginning of the experiment. Over a $30 \mathrm{~d}$ period no repeated reversals occurred (Chornesky 1989).

Dominance did not occur in isogenic experiments (Table 4). Dominance was observed in the intramorphic contacts but was outnumbered by the total of non- and equal-aggression contacts. Comparing the results of the isogenic contacts with those from the 
Table 3. Montastrea annularis. Probabilities from Chi-square tests for deviation from Hardy-Weinberg equilibrium for all polymorphic loci of the morphotype complex on Curaçao. sf = small frequencies; $-=$ monomorphic; $\mathrm{B}=$ bumpy; $\mathrm{C}=\mathrm{Columnar}$; $\mathrm{M}=$ Massive $\mathrm{AB}=$ Awa Blancu; $\mathrm{B} 1=\mathrm{Buoy} 1 ; \mathrm{SB}=$ Slangenbaai. Significant values in bold type

\begin{tabular}{|c|c|c|c|c|c|c|c|c|c|}
\hline \multirow[t]{2}{*}{ Locus } & \multicolumn{9}{|c|}{ Morphotype/Location } \\
\hline & $\mathrm{B} / \mathrm{AB}$ & $\mathrm{B} / \mathrm{B} 1$ & $\mathrm{~B} / \mathrm{SB}$ & $\mathrm{M} / \mathrm{AB}$ & $\mathrm{M} / \mathrm{B} 1$ & $\mathrm{M} / \mathrm{SB}$ & $\mathrm{C} / \mathrm{AB}$ & $\mathrm{C} / \mathrm{B} 1$ & $\mathrm{C} / \mathrm{SB}$ \\
\hline Tpi-1 & sf & - & - & .847 & sf & - & sf & .058 & $5 f$ \\
\hline$T p i-2$ & 908 & .467 & .886 & sf & .886 & .744 & .034 & .681 & sf \\
\hline Gpi-1 & .051 & .194 & .611 & .847 & - & sf & .517 & .516 & sf \\
\hline$M e-1$ & sf & .814 & .053 & .963 & .073 & .054 & .053 & .081 & .239 \\
\hline Gdh-1 & - & - & - & - & - & - & - & - & - \\
\hline Gdh-2 & .371 & .599 & .296 & .026 & .908 & .599 & 154 & .168 & .687 \\
\hline Pgm-1 & .901 & .000 & .040 & .089 & .043 & .014 & 905 & sf & .646 \\
\hline Ltp-1 & .098 & .358 & .371 & .530 & .073 & 311 & .273 & .339 & .905 \\
\hline$L p p-1$ & .036 & .095 & .380 & .959 & .278 & .814 & .003 & .002 & .001 \\
\hline
\end{tabular}

intra-morphic contacts, only the Bumpy morphotype showed a significant difference: an increase in dominant interactions (Chi-square test, $\mathrm{p}<0.01$ ).

The frequency distribution in the isogenic experiments shows that the Columnar morphotype only scored in the category 'equal aggression'; this is a significant difference (Chi-square test, $p<0.001$ ) when tested against the 2 other morphotypes.

The number of dominant scores in the inter-morphic contacts is high, and the proportions differed significantly from the intra-morphic contacts (Chi-square tests, $\mathrm{p}<0.001$ ). In a hierarchical ranking, Bumpy was dominant over the other 2 morphotypes and Massive was dominant over Columnar.
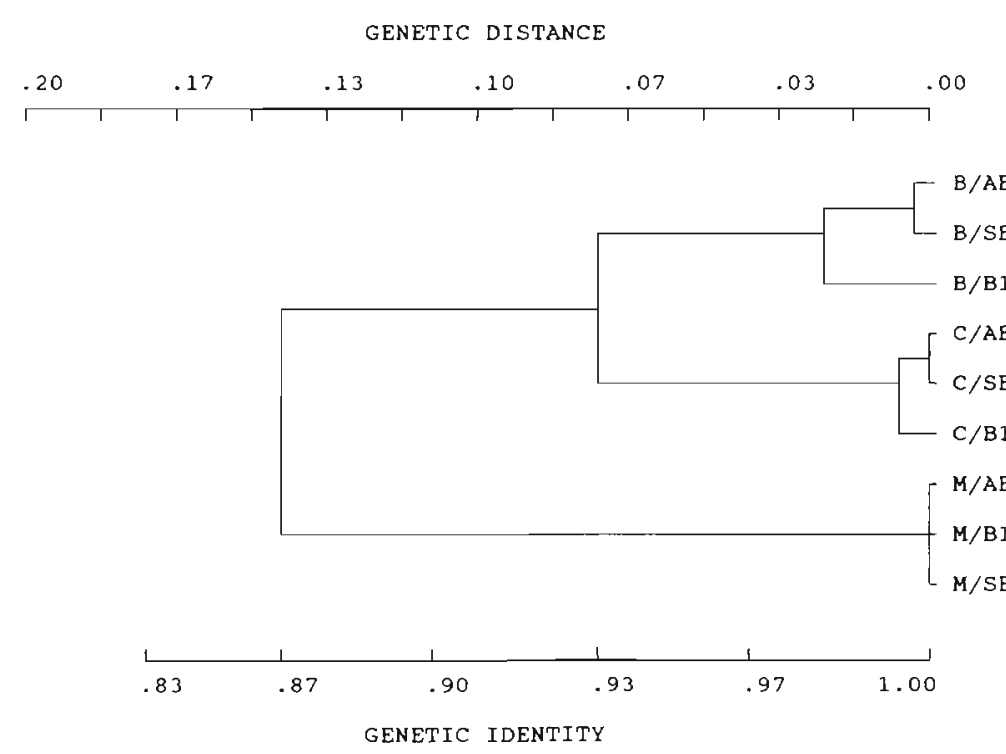

Fig. 4. Cluster dendogram based on Nei's (1978) unbiased genetic distance (upper $x$-axis) and genetic identity (lower $x$-axis) coefficients for comparisons of 9 loci in the Caribbean coral Montastrea annularis from 3 sampling sites on the leeward coast of Curaçao. (Abbr.: $\mathrm{B}=\mathrm{Bumpy} ; \mathrm{C}=$ Columnar; $\mathrm{M}=$ Massive $\mathrm{AB}=\mathrm{Awa}$ Blancu; $\mathrm{B} 1=$ Boei $1 ; \mathrm{SB}=$ Slangenbaai)

\section{Electrophoresis versus interaction results}

The mean number of alleles shared by 1 of the 3 possible outcomes of interaction ranged from 62.01 to $66.22 \%$ for no interaction and dominance, respectively. No significant differences were found by a 2way ANOVA $\left(F_{[2,43]}=0.02\right)$ between the interaction outcome and the percentage of alleles shared between the 2 opponents.

\section{Morphometrics}

Micro-morphometrics. A single classification ANOVA was carried out to test for significant differences between means of micro-morphological measurements (Table 5). For the Columnar morphotype, data of the apex of the colony and side measurements differed significantly only for one character, corallite spacing (min) (Table 6; ANOVA, $p<0.05)$. Consequently these data were pooled in further comparisons. Bumpy tested against Massive and Columnar resulted in 12 and 11 significantly different characters respectively (Table 6; ANOVA, $p<0.05)$. Only 6 were different when testing Massive against Columnar. The character $\mathrm{CaS}$-min was the only one differing significantly when comparing all test possibilities.

Macro-morphometrics. Within the Columnar morphotype the number of polyps on the apex of the colony was significantly higher than that on the side (Table 6 ; ANOVA, $p<0.001$ ). To facilitate comparison with the 2 other morphotypes, only the apex measurements were used in further testing. The number of polyps per 
Table 4. Montastrea annularis. Scores in interaction experiments. $\mathrm{B}=$ Bumpy; $\mathrm{M}=$ Massive $; \mathrm{C}=$ Columnar $\mathrm{N}=$ total of scored observations. Observed scores see text

\begin{tabular}{|c|c|c|c|c|}
\hline \multirow{2}{*}{ Experiment } & \multicolumn{3}{|c|}{ Observed scores } & \multirow[t]{2}{*}{$N$} \\
\hline & None & Equal & Dominant & \\
\hline \multicolumn{5}{|c|}{ Isogenic contacts } \\
\hline$B-B$ & 60 & 7 & 0 & 67 \\
\hline$M-M$ & 46 & 3 & 0 & 49 \\
\hline$C-C$ & 0 & 51 & 0 & 51 \\
\hline \multicolumn{5}{|c|}{ Intra-morphic contacts } \\
\hline$B-B$ & 13 & 9 & 11 & 33 \\
\hline$M-M$ & 35 & 4 & 7 & 46 \\
\hline$C-C$ & 4 & 43 & 2 & 49 \\
\hline \multicolumn{5}{|c|}{ Inter-morphic contacts } \\
\hline 1st 2nd & & & 1st 2 nd & \\
\hline$\overline{B-M}$ & 7 & 2 & $31-2$ & 42 \\
\hline$B-C$ & 0 & 6 & $35-0$ & 41 \\
\hline$M-C$ & 4 & 9 & $33-3$ & 49 \\
\hline
\end{tabular}

surface unit was significantly different between the morphotypes (Table $6 ; 2$-way ANOVA, $p<0.001$ ), but there was no significant difference between localities.

\section{DISCUSSION}

Our experiments on intraspecific variation in the coral species Montastrea annularis showed significant differences in genetical, behavioral and morphometric aspects of the 3 morphotypes from Curaçao and Bonaire.

There is evidence that the banding pattern of Montastrea annularis in electrophoretic analysis is polymorphic (Ohlhorst 1979). In our study $M$. annularis displays a high genetic variability, indicated by a high mean heterozygosity $(0.36)$ and mean of alleles per locus (4.7), which can be correlated with morphological characters. Olhorst (1979), in her pioneering study, found no correlation between allelic composition and colony shape or tissue color, but thought allelic composition to be related to locality.

We show that genetic variation is not a local phenomenon; all localities on Curaçao and Bonaire (Van Veghel unpubl.) display a comparable pattern in allelic frequencies. From a total of 46 alleles examined in this study and in Panama (Knowlton et al, 1992), 5 were not found in Panama and 4 were not found in this study. These were all alleles with a mean frequency of $7 \%$ or lower. Common alleles were not restricted to local populations.

No fixed or nearly fixed differences were found in the allelic composition. In contrast, Knowlton et al. (1992) found 5 (nearly) fixed differences using the same loci comparing Montastrea annularis with its
Table 5. Montastrea annularis. Average values (in $\mathrm{mm}$ ) and standard deviations of morphometric measurements in the 3 different morphotypes. $\mathrm{N}$ polyps $=$ number of polyps per $7.6 \mathrm{~cm}^{2}$ a $=$ colony apex; $\mathrm{s}=$ colony side. For other abbreviations and descriptions see Table 1

\begin{tabular}{|c|c|c|c|c|}
\hline \multicolumn{2}{|c|}{ Measurement } & \multirow{2}{*}{$\begin{array}{c}\text { Bumpy } \\
3.84(0.66)\end{array}$} & \multirow{2}{*}{$\frac{\text { Massive }}{3.40(0.46)}$} & \multirow{2}{*}{$\begin{array}{l}\text { Columnar } \\
3.32(0.53)\end{array}$} \\
\hline 1. $\mathrm{CuD}$ & $\min$ & & & \\
\hline & $\max$ & $5.33(1.20)$ & $4.43(0.87)$ & $4.23(0.71)$ \\
\hline \multirow[t]{2}{*}{ 2. $\mathrm{CaS}$} & $\min$ & $1.36(0.44)$ & $1.10(0.38)$ & $0.98(0.34)$ \\
\hline & $\max$ & $2.17(0.64)$ & $1.77(0.41)$ & $1.83(0.54)$ \\
\hline \multirow[t]{2}{*}{ 3. $\mathrm{CaD}$} & $\min$ & $2.38(0.33)$ & $2.35(0.18)$ & $2.34(0.21)$ \\
\hline & $\max$ & $2.62(0.34)$ & $2.54(0.22)$ & $2.52(0.24\}$ \\
\hline \multirow[t]{2}{*}{ 4. CuW } & $\min$ & $1.04(0.21)$ & $0.96(0.16)$ & $1.01(0.13)$ \\
\hline & $\max$ & $1.22(0.28)$ & $1.13(0.18)$ & $1.16(0.16)$ \\
\hline \multirow[t]{2}{*}{ 5. PsL } & $\min$ & $0.67(0.11)$ & $0.70(0.08)$ & $0.65(0.11)$ \\
\hline & $\max$ & $0.83(0.15)$ & $0.81(0.09)$ & $0.79(0.12)$ \\
\hline \multirow[t]{2}{*}{ 6. PsT } & $\min$ & $0.22(0.09)$ & $0.23(0.03)$ & $0.21(0.07)$ \\
\hline & $\max$ & $0.31(0.10)$ & $0.30(0.04)$ & $0.30(0.09)$ \\
\hline \multirow[t]{2}{*}{ 7. SsL } & $\min$ & $0.20(0.05)$ & $0.17(0.05)$ & $0.17(0.05)$ \\
\hline & $\max$ & $0.31(0.08)$ & $0.30(0.08)$ & $0.25(0.07)$ \\
\hline \multirow[t]{2}{*}{ 8. Ss T } & mLin & $0.16(0.03)$ & $0.15(0.03)$ & $014(0.03)$ \\
\hline & $\max$ & $0.24(0.04)$ & $0.24(0.05)$ & $0.21(0.04)$ \\
\hline \multirow[t]{2}{*}{ 9. ThL } & $\min$ & $0.40(0.09)$ & $0.42(0.09)$ & $0.42(0.09)$ \\
\hline & $\max$ & $0.58(0.11)$ & $0.58(0.09)$ & $0.58(0.10)$ \\
\hline \multirow[t]{2}{*}{ 10. ThW } & $\min$ & $0.31(0.06)$ & $0.30(0.05)$ & $0.31(0.07)$ \\
\hline & $\max$ & $0.42(0.07)$ & $0.39(0.06)$ & $0.39(0.06)$ \\
\hline \multicolumn{2}{|l|}{ 11. PsC } & $11.92(0.58)$ & $11.95(0.44)$ & $12.06(0.55)$ \\
\hline \multicolumn{2}{|c|}{ 12. $\mathrm{SsC}$} & $11.92(0.58)$ & $11.95(0.44)$ & $12.05(0.59)$ \\
\hline \multirow{2}{*}{\multicolumn{2}{|c|}{ 13. N polyps }} & $28.55(5.98)$ & $38.54(6.60)$ & a $40.97(5.88)$ \\
\hline & & & & s $35.52(5.43)$ \\
\hline
\end{tabular}

sympatric congener Montastrea cavernosa (Linnaeus). The Nei's unbiased genetic distances for Curaçao and Panama are respectively: Massive - Columnar $=0.13$, 0.24 ; Massive - Bumpy $=0.16,0.26$; and Columnar Bumpy $=0.07,0.06$. Values for Panama are appreciably higher than in Curaçao morphs. These differences are probably due to geographic variation, since the environmental parameters and species history of the populations are quite different.

Although a strict relation between systematic divergence and genetic measures is not generally accepted (Menken \& Ulenberg 1987), Thorpe (1983) suggests that a genetic identity value (Nei 1978) between most conspecific populations should be above 0.9 , where congeneric species fall within the range between 0.25 and 0.85 . The genetic identity we found points to levels characteristic for conspecific populations. Coral taxonomy is based on the morphological distinctness of species, but at present the biological species concept is the most widely used (Coyne et al. 1988). We think the reproductive biology should be studied before deciding on the taxonomic status of Montastrea annularis morphotypes.

Montastrea annularis shows a high mean heterozygosity, $H=0.36$, compared with a mean for marine invertebrates of $H=0.15$, and an overall mean of $H=$ 
Table 6. Montastrea annularis. Single Classification ANOVA with 2 and 3 groups of morphometric measurements concerning the 3 different morphotypes. Significance: $\cdots p<0.001$; $\because 0.01<p<0.001 ; \cdot 0.01<p<0.05 ; n s=$ not significant. $B=$ Bumpy; $\mathrm{M}=$ Massive; $\mathrm{C}=$ Columnar; $\mathrm{Ca}=$ columnar apex; $\mathrm{Cs}=$ columnar side. $\mathrm{N}$ polyps = number of polyps per square unit. For abbreviations and descriptions of characters see Table 1

\begin{tabular}{|c|c|c|c|c|c|c|}
\hline \multicolumn{2}{|c|}{ Character } & \multirow{2}{*}{$\frac{B-M}{\ldots}$} & \multirow{2}{*}{$\frac{B-C}{\ldots}$} & \multirow{2}{*}{$\frac{M-C}{n s}$} & \multirow{2}{*}{$\begin{array}{c}B-M-C \\
\ldots\end{array}$} & \multirow{2}{*}{$\frac{\mathrm{Ca}-\mathrm{Cs}}{\mathrm{ns}}$} \\
\hline CuD & $\min$ & & & & & \\
\hline & $\max$ & $\ldots$ & $\cdots$ & ns & $\ldots$ & ns \\
\hline \multirow[t]{2}{*}{$\mathrm{CaS}$} & $\min$ & $\ldots$ & $\ldots$ & $\cdot$ & $\cdots$ & $\because$ \\
\hline & $\max$ & $\ldots$ & $\cdots$ & ns & $\ldots$ & ns \\
\hline \multirow[t]{2}{*}{$\mathrm{CaD}$} & $\min$ & ns & ns & ns & ns & ns \\
\hline & $\max$ & $\cdot$ & $\cdot$ & ns & $\cdot$ & ns \\
\hline \multirow{2}{*}{$\mathrm{CuW}$} & $\min$ & . & ns & $\cdot$ & .. & ns \\
\hline & $\max$ & $\cdots$ & ns & ns & $\cdot$ & ns \\
\hline \multirow[t]{2}{*}{ PsL } & $\min$ & . & ns & $\cdots$ & .. & ns \\
\hline & $\max$ & ns & $\cdot$ & ns & $\cdot$ & ns \\
\hline \multirow{2}{*}{ PsT } & $\min$ & ns & ns & ns & ns & ns \\
\hline & $\max$ & ns & ns & ns & ns & ns \\
\hline \multirow[t]{2}{*}{ SsL } & $\min$ & $\cdots$ & $\cdots$ & ns & $\cdots$ & ns \\
\hline & $\max$ & ns & $\ldots$ & $\cdots$ & $\cdots$ & ns \\
\hline \multirow[t]{2}{*}{ SsT } & $\min$ & $\cdots$ & $\cdots$ & ns & $\cdots$ & ns \\
\hline & $\max$ & ns & $\ldots$ & $\cdots$ & $\cdots$ & ns \\
\hline \multirow[t]{2}{*}{ ThL } & $\min$ & ns & ns & ns & ns & ns \\
\hline & $\max$ & ns & ns & $\mathrm{ns}$ & ns & ns \\
\hline \multirow{2}{*}{ ThW } & $\min$ & $\cdot$ & ns & $\cdot$ & ns & ns \\
\hline & $\max$ & $\cdots$ & $\cdots$ & ns & $\ldots$ & ns \\
\hline \multicolumn{2}{|l|}{ PsC } & ns & ns & ns & ns & ns \\
\hline \multicolumn{2}{|l|}{$\mathrm{SsC}$} & ns & ns & ns & ns & ns \\
\hline \multicolumn{2}{|c|}{ N polyps } & $\ldots$ & $\ldots$ & $\ldots$ & $\cdots$ & $\cdots$ \\
\hline
\end{tabular}

0.10 (Ferguson 1980). In general, heterozygosity and fitness are thought to be positively correlated (Mayr 1970). Nevo et al. (1984) summarized the various ways that high heterozygosity can be established or maintained. However, they did not find direct cause-effect relationships between biotic and genetic factors. The longevity of $M$. annularis colonies, which makes a multi-generation gamete exchange possible, may be responsible for the high heterozygosity.

Despite the high heterozygosity, we found that the number of heterozygotes observed is consistent with expectations. An exception is taxonomic unit $\mathrm{B} / \mathrm{SB}$, showing a significant $(G$-test, $\mathrm{p}<0.005)$ deficiency in the number of expected heterozygotes.

The Hardy-Weinberg equilibrium is based on conditions of random mating if the genes are of equal selective value (Mayr 1970). A high percentage, $26 \%$, of the polymorphic loci tested departs (Chi-square, $p<0.06$ ) from the Hardy-Weinberg equilibrium. Stoddart (1983) also found high disequilibria resulting from proliferation of relatively few genotypes, indicated by identical genotypes. In our case, all colonies sampled were genotypically unique. Montastrea annularis eggs are externally fertilized (Szmant 1986, Van Veghel pers. obs.), so mating presumably will be random and self fertilization is not to be expected. A preliminary explanation for this high percentage of Hardy-Weinberg deviations could lie in an unequal selective value of the alleles.

The genetic variability could have been affected by sampling from a broad range of generations. As it is not possible to determine genetic age in corals, the genetic age of a sample may vary from several years to hundreds of years. If the genetic sampling involved in transmission of genes between generations is random, any extant population is a random representative of all the replicate populations that may arise under the same set of conditions (Weir 1990). For this analysis we assumed that the 9 examined loci are representative for the overall genomic variation.

The results of the isogenic interaction experiments demonstrated dominant interactions to be absent within morphotypes. This is in contrast to intra-morphic and inter-morphic experiments where dominance was found in all morphotypes. The inter-morphic contact experiments show a clear polymorphic distinction between the morphotypes in behavior. The hierarchical ranking from more to less dominant, Bumpy > Massive > Columnar, is the same as between these morphotypes in Panama (Knowlton et al. 1992).

No relationship was found between interaction outcomes and the percentage of alleles shared between 2 individuals. This could mean that the interactive response is a phenotypic characteristic or, more likely, that the fraction of the genotype examined electrophoretically is not representative of the genotypic differences determining interaction outcomes (Stoddart et al. 1985).

Foster (1977) showed that there are small-scale variations in skeletal morphology within Montastrea annularis in relation to the environment. She did not find a corallite character that could be used for a direct prediction of colony shape or vice versa, because measured ranges overlapped (Foster 1983). We demonstrate significant differences between micro-morphological characteristics of the morphotypes, but these cannot be used as a taxonomic characteristic. When comparing Massive and Columnar corallites, fewer differences were observed than when comparing these with the Bumpy morphotype. This contrasts with the genetic variance where the Massive morph is the one differing most.

The differing number of polyps per square unit of area (ANOVA, $p<0.01$ ) is explained by the differences found in corallite spacing (ANOVA, $p<0.05$ ), because the corallite diameter was not very different between the morphotypes.

Skeletal variation between the apex and side of the columnar morph within a colony was also found by 
Land et al. (1975). At the side, this showed as slower rates of calcification, more widely separated calices, scarcely distinguishable theca, less exsert septa and highly developed dentations. We found significant differences in the minimum spacing of the corallite and the number of polyps per square unit. Foster (1977) claimed this is due to micro-environmental factors. Tissue is found only over the top of the columns; die-off of the polyps on the side of the columns must be related to unfavorable conditions on the side of the column.

In conclusion, we demonstrate that the present Montastrea annularis population in Curaçao is comprised of at least 3 recognizable morphotypes. Characters which define genetic, behavioral and morphological aspects show significant differences. However, none of these characters are fixed for all 3 morphotypes, and so far they cannot be used as a diagnostic tool. Studies on reproductive biology and ecological characteristics are necessary to define the status of the M. annularis morphotypes.

Acknowledgements. We thank Lee Weigt and Eyda Gomez for their assistance and support in the electrophoresis lab. Dr Nancy Knowlton and Ernesto Weil gave the first author the opportunity to learn electrophoretic techniques and to use their protocols. We are grateful to the CARMABI foundation and diving buddies for their help during collections. Dr Harilos Lessios supported the first author during his stay at the Smithsonian Tropical Research Institute. Prof. Steph Menken and 2 anonymous reviewers provided valuable comments on the manuscript. This research was financially supported by the Department of Biology of the University of Amsterdam and by a Smithsonian Short-term Fellowship

\section{LITERATURE CITED}

Ayre, D. J., Veron, J. E. N., Dufty, S. C. (1991). The corals Acropora palifera and Acropora cuneata are genetically and ecologically distinct. Coral Reefs 10: 13-18

Bak, R. P. M., Brouns, J. J W. M, Heys, F. M. L. (1977). Regeneration and aspects of spatial competition in the scleractinian corals Agaricia agaricites and Montastrea annularis. Proc. 3rd Int. Coral Reef Symp. Miami 1 . $143-148$

Bak, R. P. M., Engel, M. S. (1979). Distribution, abundance and survival of juvenile hermatypic corals (Scleractinia) and the importance of life history strategies in the parent coral community. Mar. Biol. 54: 341-352

Bak, R. P. M., Luckhurst, B. E. (1980). Constancy and change in coral reef habitats along depth gradients at Curaçao Oecologia 47: 145-155

Bak, R. P. M., Termaat, R. M., Dekker, R. (1982). Complexity of coral interactions, influence of time, location of interaction and epifauna. Mar. Biol. 69: 215-222

Barnes, D. J (1973). Growth in colonial scleractinians. Bull mar. Sci. 23: $280-298$

Chornesky, E. A. (1989). Repeated reversals during spatial competition between corals. Ecology 70(4): 843-855

Coyne, J. A., Orr, H. A., Futuyma, D. J. (1988). Do we need a new species concept? Syst. Zool. 37: 190-200
Dodge, R. E. (1982). Effects of drilling mud on the reef-building coral Montastrea annularis. Mar. Biol. 71: 141-147

Dustan, P. (1975). Growth and form in the reef-building coral Montastrea annularis. Mar. Biol. 33: 101-107

Ferguson, A. (1980). Biochemical systematics and evolution Blackie, London

Foster, A. B. (1977). Patterns of small-scale variation of skeletal morphology within the scleractinian corals, Montastrea annularis and Siderastrea siderea. Proc. 3rd Int. Coral Reef Symp. Miami 2: 409-415

Foster, A. B. (1979). Phenotypic plasticity in the reef corals Montastrea annularis (Ellis and Solander) and Siderastrea siderea (Ellis and Solander). J. exp. mar. Biol. Ecol. 39 $25-54$

Foster, A. B. (1983). The relationship between corallite morphology and colony shape in some massive reef corals Coral Reefs 2: 19-25

Gladfelter, W. B. (1982). White-band disease in Acropora palmata: implications for the structure and growth old shallow reefs. Bull. mar. Sci. 32(2): 639-643

Goenaga, C. (1988). The distribution and growth of Montastrea annularis (Ellis and Solander) in Puerto Rican inshore platform reefs. Ph.D. thesis, University of Puerto Rico

Graus, R. R., Macintyre, I. G. (1982). Variation in the growth forms of the reef coral Montastrea annularis (Ellis and Solander): a quantitative evaluation of growth response to light distribution using computer simulation. In: Rutzler K., MacIntyre, I. G. (eds.) The Atlantic Barrier Reef ecosystem at Carrie Bow Cay, Belize. 1. Structure and communities. Smithson. Contri. mar. Sci. 12: 441-464

Hayes, R. L., Bush, P. G. (1990). Microscopic observations of recovery in the reef-building scleractinian coral, Montastrea annularis, after bleaching on a Cayman Reef. Coral Reefs 8(4): 203-209

Hudson, J. H. (1981a). Growth rates in Montastrea annularis A record of environmental change in Key Largo Coral Reef Marine Sanctuary, Florida. Bull. mar. Sci. 31(2): $444-459$

Hudson, J. H. (1981b). Response of Montastrea annularis to environmental change in the Florida Keys. Proc. 4th Int Coral Reef Symp., Manila 2: 234-240

Hughes, T. P., Jackson, J. B. C. (1980). Do corals lie about their age? Some demographic consequences of partial mortality, fission and fusion. Science 209: 713-715

Knowlton, N., Weil, E., Weigt, L. A., Guzmán, H. (1992) Sibling species in Montastrea annularis, coral bleaching, and the coral climate record. Science 255: 330-332

Land, L. S., Lang, J. C., Barnes, D. J. (1975). Extension rate: a primary composition of West Indian (Jamaican) Scleractinian reef coral skeletons. Mar. Biol. 33: 221-233

Lang, J. (1973). Interspecific aggression by scleractinian corals. 2 . Why the race is not only to the swift. Bull. mar. Sci. 23(2): $260-279$

Lester, R. T., Bak, R. P. M. (1985). Effects of environment on regeneration rate of tissue lesions in the reef coral Montastrea annularis (Scleractinia). Mar. Ecol. Prog. Ser 24: $183-185$

Mayr, E. (1970). Populations, species and evolution. Harvard University Press, Cambridge

Meesters, E. H., Bak, R. P. M. (1993). Effects of coral bleaching on tissue regeneration potential and colony survival Mar. Ecol. Prog. Ser. (in press)

Menken, S. B. J., Ulenberg, S. A. (1987). Brochemical characters in agricultural entomology. Agricult. Zool. Rev. 2 $305-359$

Nevo, E., Beiles, A., Ben-Shlomo, R. (1984). The evolutionary 
significance of genetic diversity: ecological, demographic and life history correlates. Lecture Notes in Biomathematics 53: 13-213

Nei, M. (1978). Estimation of average heterozygosity and genetic distance from a small number of individuals. Genetics 89: 583-590

Ogden, J. C., Gladfelter, E. H. (1986). Caribbean coastal marine productivity (CARICOMP). UNESCO Rep. mar. Sci. 410

Ohlhorst, S. L. (1979). The use of polyacrylamide gel electrophoresis in coral taxonomy. Palaeontographica Americana 54: $45-48$

Parker, J. H., Nickels, J. S., Marts, R. F., Gehrom, M. J., Richards, N. L., White, D. C. (1984). Effect of well drilling fluids on the physiological status and microbial infection of the reef building coral Montastrea annularis. Arch. environ. Contam. Toxicol. 13(1): 113-118

Porter, J. W. (1985). The maritime weather of Jamaica: its effects on annual carbon budgets of the massive reef-building coral Montastrea annularis. Proc. 5th Int. Coral Reef Symp., Tahiti 6: 634-367

Ramos-Flores, T. (1983). Lower marine fungus associated with black line disease in star corals (Montastrea annularis, E. en S.). Biol. Buil. 165: 429-435

Roos, P. J. (1967). Growth and occurrence of the reef coral Porites asteroides Lamarck in relation to submarine radiance distribution. Academisch Proefschrift, Universiteit var Amsterdam

Roos, P. J. (1971). The shallow-water stony coral of the Netherlands Antilles. Stud. Fauna Curaçao 37: 1-108

Siegel, S. (1956). Nonparametric statistics. McGraw-Hill, Tokyo

Sokal, R. R., Rohlf, F. J. (1981). Biometry. W. H. Freeman and Co., New York

Stephenson, T. A., Stephenson, A. (1933). Growth and asexual reproduction in corals. Sci. Rep. Great Barrier Reef Exped. 1928-1929 Br. Mus. (Nat. Hist.) 3(7): 167-217

Stoddart, J. A. (1983). Asexual production of planulae in the coral Pocillopora damicornis. Mar. Biol. 76: 279-286

Stoddart, J. A. (1984a). Genetical structure within populations of the coral Pocillopora damicornis. Mar. Biol. 81: 19-30

Stoddart, J. A. (1984b). Genetic differentiation amongst populations of the coral Pocillopora damicornis of Southwestern Australia. Coral Reefs 5: 43-53

Stoddart, J. A., Ayre, D. J., Willis, B., Heyward, A. J. (1985). Self-recognition in sponges and corals? Evolution 39 : $461-463$

This article was submitted to the editor
Swofford, D. L., Selander, R. B. (1981). Biosys-1. a FORTRAN program for the comprehensive analysis of electrophoretic data in population genetics and systematics. J Hered. 72: $281-283$

Szmant, A. M. (1986). Reproductive ecology of Caribbean reef corals. Coral Reefs 3: 149-156

Szmant, A. M., Gassman, N. J (1990). The effects of prolonged 'bleaching' on the tissue biomass and reproduction of the reef coral Montastrea annularis. Coral Reefs 8: $217-224$

Szmant-Froelich, A. (1985). The effect of colony size on the reproduction ability of the Caribbean coral Montastrea annularis. Proc. 5th Int. Coral Reef Symp., Tahiti 4: 295-300

Szmant-Froelich, A., Johnson, V., Hoelin, T., Battey, J., Smith, G. J., Fleischmann, E., Porter, J., Dallmeyer, D. (1981). The physiological effects of oil-drilling muds on the Caribbean coral Montastrea annularis. Proc. 4th Int. Coral Reef Symp., Manila 1: 163-168

Thorpe, J. P. (1983). Enzyme variation, genetic distance and evolutionary divergence in relation to levels of taxonomic separation. In: Oxford, G. S., Rollinson, D. (eds.) Protein polymorphism: adaptive and taxonomic significance. Academic Press, London, p. 131-152

Tomascik, T. (1990). Growth rates of two morphotypes of Montastrea annularis along a eutrophication gradient, Barbados, W.I. Mar. Pollut. Bull. 21(8): 376-381

Tomascik, T., Sander, F. (1987). Effects of eutrophication on reef-building corals. II. Structure of scleractinian coral communities on fringing reefs, Barbados, West Indies. Mar. Biol. 94: 53-75

Van Duyl, F. C. (1985). Atlas of the living reef of Curaçao and Bonaire (Netherlands Antilles). Foundation for Scientific Research in Surinam and the Netherlands Antilles. Vol. 117. Utrecht, p. 37

Weir, B. S. (1990). Intraspecific differentiation. In: Hillis, D. M., Moritz, C. (eds.) Molecular systematics. Sinauer Associates, Inc., Sunderland, p. 373-410

Wijsman-Best, M. (1974). Habitat induced modification of reef corals (Faviidae) and its consequences for taxonomy. Proc. 2nd Int. Symp. Coral Reefs, Brisbane 2: 217-228

Willis, B. L., Ayre, D. J. (1985). Asexual reproduction and genetic determination of growth form in the coral Pavona cactus: biochemical genetic and immunogenic evidence. Oecologia 65: 516-525

Wood-Jones, F. (1907). On the growth forms and supposed species in corals. Proc. Zool. Soc. Lond., p. 518-556

Manuscript first received: June 1, 1992

Revised version accepted: December 8,1992 